Saudi Journal of Medicine

Abbreviated Key Title: Saudi J Med ISSN 2518-3389 (Print) |ISSN 2518-3397 (Online) Scholars Middle East Publishers, Dubai, United Arab Emirates Journal homepage: https://saudijournals.com

Original Research Article

\title{
Diagnosis of COVID 19 (SARS CoV 2) By Two Different Targets RdRp and S GENE-A Comparison Study
}

\author{
Smita Sharma ${ }^{1 *}$, Rami Abdullah Ali Al Dagrer ${ }^{2}$, Anshu Rajnish Sharma ${ }^{3}$ \\ ${ }^{1}$ MD, DTCD, Clinical Biochemist, Molecular Biology Section, Regional Laboratory, Nejran, KSA \\ ${ }^{2}$ Director Laboratories and Blood Banks and Director Regional Laboratory, Nejran, KSA \\ ${ }^{3}$ Consultant and Dean Nuclear Medicine, Kokilaben Dhirubhai Ambani Hospital, Mumbai, India
}

DOI: $10.36348 /$ sjm.2020.v05i12.006

| Received: 14.12.2020 | Accepted: 23.12.2020 | Published: 24.12.2020

*Corresponding Author: Smita Sharma

\section{Abstract}

Beta-coronavirus, which caused Severe Acute Respiratory Coronavirus-2 Syndrome (SARS-CoV-2), a major respiratory outbreak in Wuhan, China in December 2019, is now prevalent in many countries around the world. Identifying PCRbased viruses is a well-known and relatively stable protocol. So diagnosis is very important for early identification of disease and to prevent further spread. In this study, we evaluated the power of a conventional RT-PCR to detect SARSCoV-2 by two different genes. Material and Methods: We did comparative analysis for RNA dependent RNA Polymerase (Rdrp gene) and Spike (S gene by) RTPCR. We took Two hundered Seventy four (274) Nasopharangeal samples came from different hospitals of Najran zone and run samples in three runs in three different runs and we did comparative analysis of Rdrp gene using Ko gene kit and S gene using Altona kit. Results: Analysis was done Qualitatively. We compared Rdrp gene with S gene. We find Sensitivity-100 \% and Specificity-96\%.In Second run Sensitivity was $100 \%$, Specificity was $98 \%$. In third run Sensitivity and Specificity was $100 \%$.So by comparative analysis of Rdrp and S gene showed that diagnosis by Rdrp gene is more sensitive and specific than S gene. Conclusion: Detection of Rdrp gene for SARS CoV2 is more sensitive and specific than Sgene.But diagnosis by Symptoms, Serology, Chest X-Ray and Chest CT Scan gives additional help.

Keywords: SARS CoV2, Rdrp gene, Sgene.

Copyright () 2020 The Author(s): This is an open-access article distributed under the terms of the Creative Commons Attribution 4.0 International License (CC BY-NC 4.0) which permits unrestricted use, distribution, and reproduction in any medium for non-commercial use provided the original author and source are credited.

\section{INTRODUCTION}

Coronavirus disease 2019 (COVID-19) is a contagious disease caused by severe acute respiratory syndrome coronavirus 2 (SARS-CoV-2). On 31 December 2019, the World Health Organization was informed of a cluster of cases of pneumonia of unknown etiology in Wuhan, China. It has since spread worldwide, leading to an ongoing pandemic. Diagnosis by Symptoms, RTPCR, Serology chest Xray and CTScans (Fig 1, 2 is gold standard.

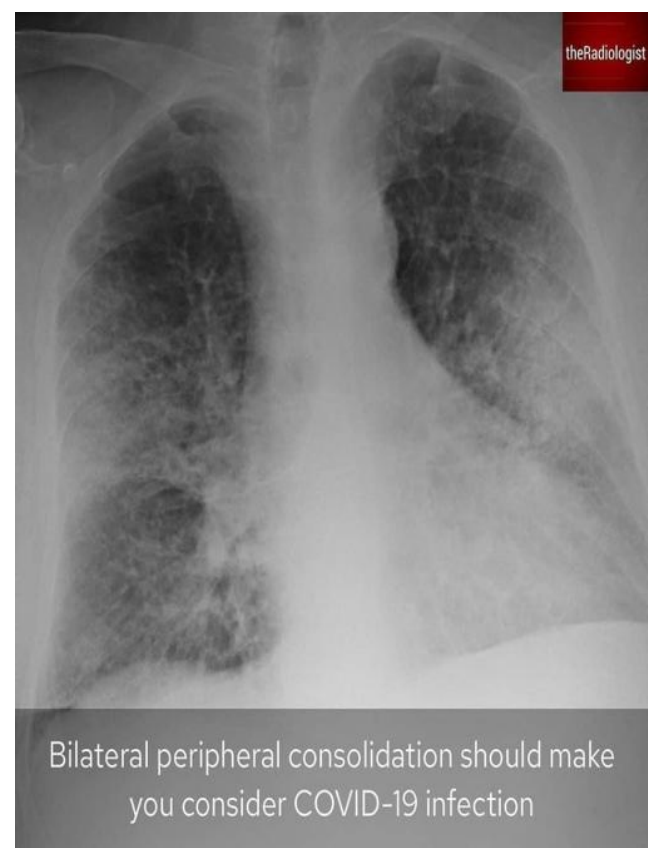

Fig-1 


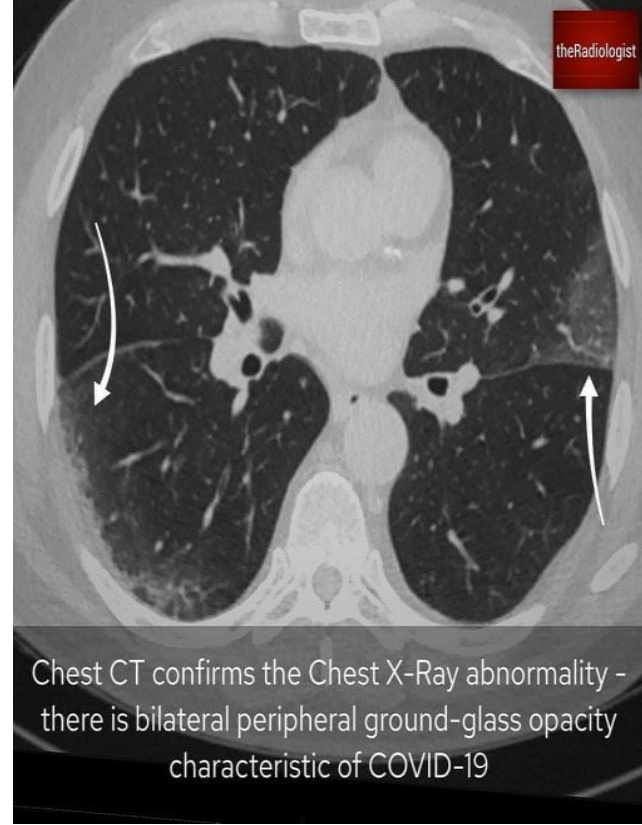

Fig-2

SARS-CoV-2 virus belongs to the B lineage of the $\beta$-coronaviruses $(\beta-\mathrm{CoVs})$; this family comprises an enveloped, non-segmented, positive-sense singlestranded RNA virus genome, with a 5' cap structure and $3^{\prime}$ poly-A tail, allowing to perform as an mRNA for translation of the replicase polyproteins [1]. Based on the data of whole-genome analyses, the genome of $\beta$ $\mathrm{CoVs}$ encodes several non-structural and four structural proteins, including spike (S), envelope (E), membrane (M), and nucleocapsid (N) [2, 3]. Among the known RNA viruses, coronaviruses, which are single-stranded and positive-sense RNA viruses have the largest genome between other RNA viruses, with the GC content ranging from $32 \%$ to $43 \%[4,5]$. The SARSCoV-2 genomic sequences exhibit a diverse length from $29.8 \mathrm{~kb}$ to $29.9 \mathrm{~kb}$ with 12 open reading frames (ORFs) encoding 27 proteins [6, 7]. The genomic organization includes 5'- leader sequence- ORF1/ab- S- ORF3a- EM- ORF6a- ORF7a- ORF7b- ORF8- N- ORF10-3' from left to right and lacks the hemagglutinin-esterase gene which is detected in some $\beta$-CoVs. A series of transcription regulatory sequences (TRS) is situated at the junction between each of these ORFs as well as at the $5^{\prime}$ end of the genomic RNA downstream of the leader sequence of $\beta$-CoVs [8]. About two-thirds of SARS-CoV-2's RNA comprises ORF1a/b region, which with 16 non-structural proteins (nsp1-16) is considered as the largest ORF. The remaining one-third of the genome near the 3 '-terminus contains ORFs encode structural and accessory proteins [2].

\section{MATERIAL AND METHODS}

Two hundered Seventy four (274) Nasopharangeal samples from suspected COVID symptoms from different hospitals in nejran zone has been taken for study. Samples run at Regional lab.Nejran in three runs by two different kits. Ko gene kit for Rdrp gene and Altona kit for $\mathrm{S}$ gene was used. RNA extraction was done by Bioneer.

The RealStar ${ }^{\circledR}$ (Altona) SARS-CoV-2 RTPCR Kit 1.0 consists of: Master A, Master B ,Positive Control (B- $\beta \mathrm{CoV}, \mathrm{SARS}-\mathrm{CoV}-2)$, Internal Control , Water (PCR grade) Master A and Master B contain all components (PCR buffer, reverse transcriptase, DNA polymerase, magnesium salt, primers and probes) to allow reverse transcription, PCR mediated amplification and detection of $\mathrm{B}-\beta \mathrm{CoV}$ (target $\mathrm{E}$ gene) specific RNA, SARS-CoV-2 (target S gene) specific RNA and Internal Control in one reaction setup.

\section{Procedure}

1. Pipette $20 \mu \mathrm{l}$ of the Master Mix into each required well of an appropriate optical 96-well reaction plate or an appropriate optical reaction tube.

2. Add $10 \mu \mathrm{l}$ of the sample (eluate from the nucleic acid extraction) or $10 \mu \mathrm{l}$ of the controls (Positive or Negative Control).

\section{Reaction Set up}

\begin{tabular}{|l|l|}
\hline Master mix & $20 \mu 1$ \\
\hline Sample or Control & $10 \mu 1$ \\
\hline Total Volume & $30 \mu 1$ \\
\hline
\end{tabular}

Reaction mixture set-up for the PowerChek ${ }^{\mathrm{TM}}$ 2019-nCoV Real-time PCR (Rdrp gene)

\begin{tabular}{|l|l|}
\hline Composition & $\begin{array}{l}\text { Volume per reaction } \\
\text { for Rdrp gene assay }\end{array}$ \\
\hline $\begin{array}{l}\text { Primer/Probe Mix 2 (RdRP } \\
\text { gene) }\end{array}$ & $4 \mu \mathrm{l}$ \\
\hline $\begin{array}{l}\text { Primer/Probe Mix (RNA } \\
\text { Process Control) }\end{array}$ & $0.5 \mu \mathrm{l}$ \\
\hline RT PCR PRE Mix & $11 \mu \mathrm{l}$ \\
\hline Total Volume & $15.5 \mu \mathrm{l}$ \\
\hline
\end{tabular}

Add the RNA Process Control (RPC) to a patient sample (5 $\mu \mathrm{L}$ of RPC for each sample).

Prepare master mix $(15.5 \mu \mathrm{L})$ and add extracted RNA $(4.5 \mu \mathrm{L})$ to make $20 \mu \mathrm{L}$ total reaction volumes. Perform RT-PCR using the appropriate realtime instrument Analyze data and interpret the results of the patient's sample.

\section{RESULTS}

90 samples were taken in run 1. Rdrp gene results were compared with $\mathrm{S}$ gene. Analysis was done in qualitative manner. In Run 1, Sensitivity was $100 \%$, Specificity was 96\%, True Positive 16, True Negative 71, False Positive 3. In Run 2, 94 samples were taken .Sensitivity was $100 \%$, Specificity was $98 \%$, True Positive-9, True Negative 83, False Positive-2. In Run 3, 94 samples were run, Sensitivity was $100 \%$, Specificity was $100 \%$, True positive-17, True Negative -77 . 
Smita Sharma et al.; Saudi J Med, Dec, 2020; 5(12): 367-374

\begin{tabular}{|l|l|l|l|l|l|l|}
\hline Total Samples & Sensitivity & Specificity & True Positive & True Negative & False Positive & False Negative \\
\hline 90 & $100 \%$ & $96 \%$ & 16 & 71 & 3 & 0 \\
\hline 94 & $100 \%$ & $98 \%$ & 9 & 83 & 2 & 0 \\
\hline 94 & $100 \%$ & $100 \%$ & 17 & 77 & 0 & 0 \\
\hline
\end{tabular}

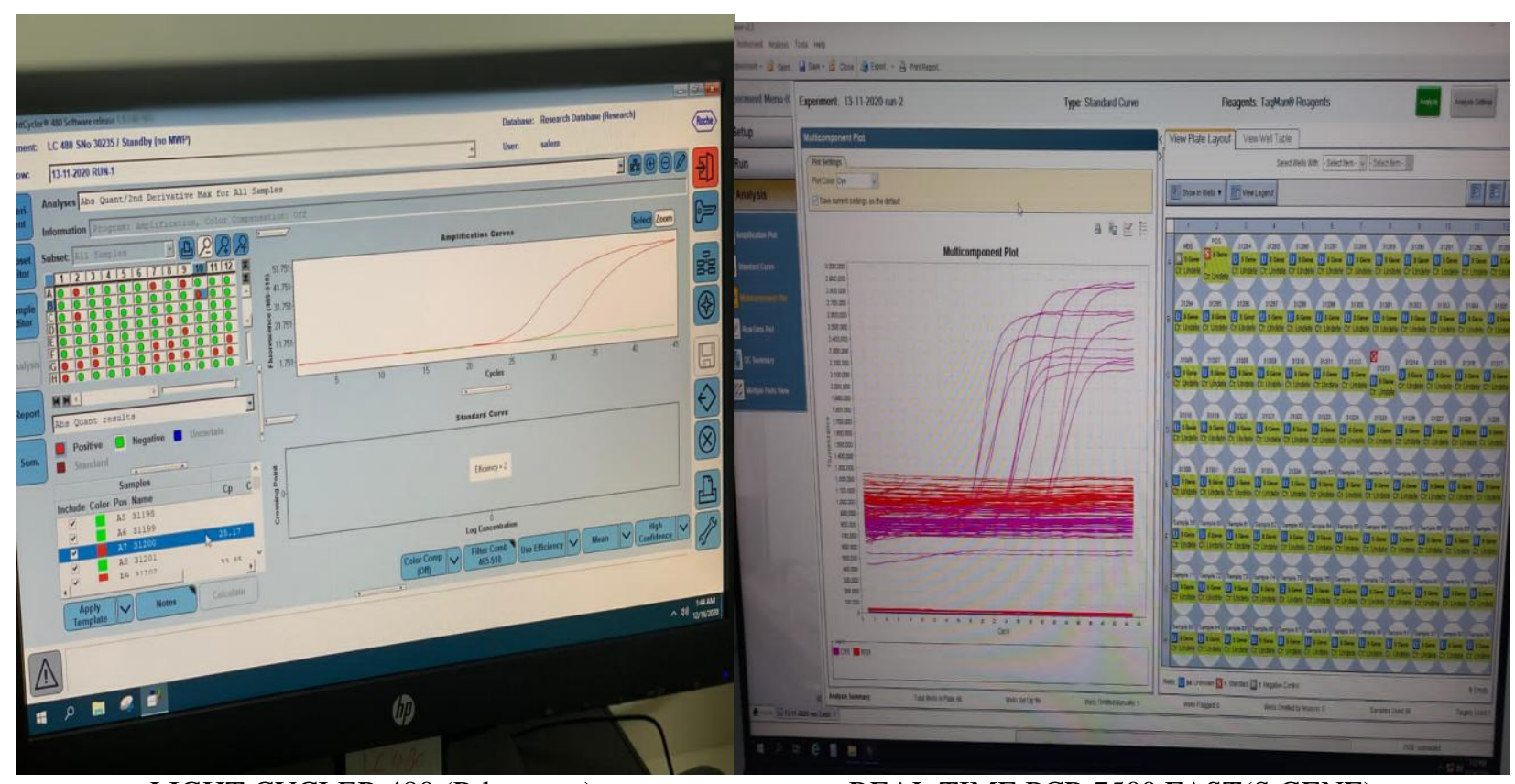

LIGHT CYCLER 480 (Rdrp gene)

REAL TIME PCR 7500 FAST(S GENE)

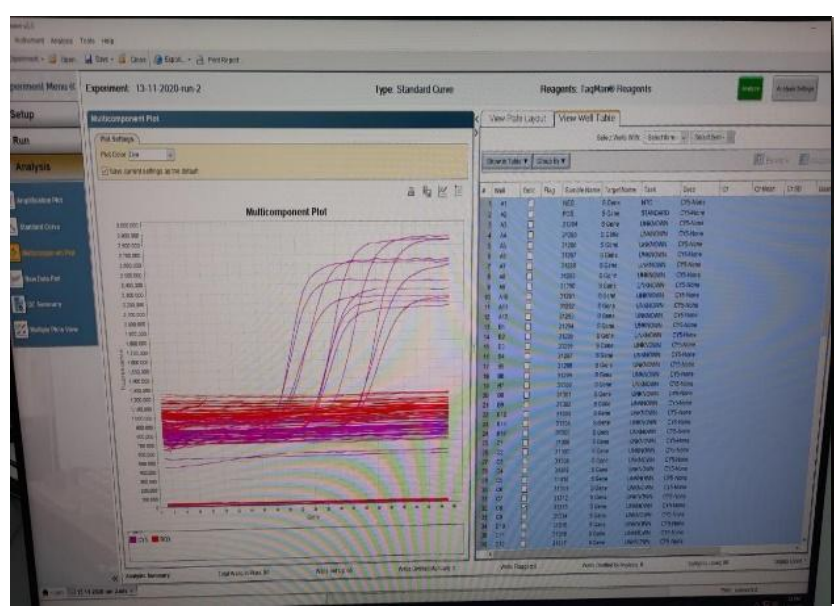

REAL TIME PCR 7500 (S GENE)

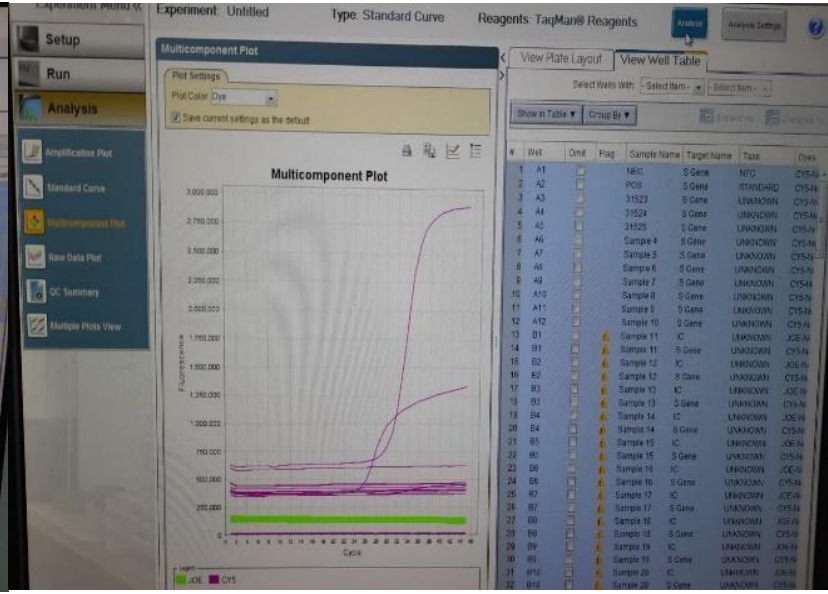

COVID POS.GRAPH 
Smita Sharma et al.; Saudi J Med, Dec, 2020; 5(12): 367-374

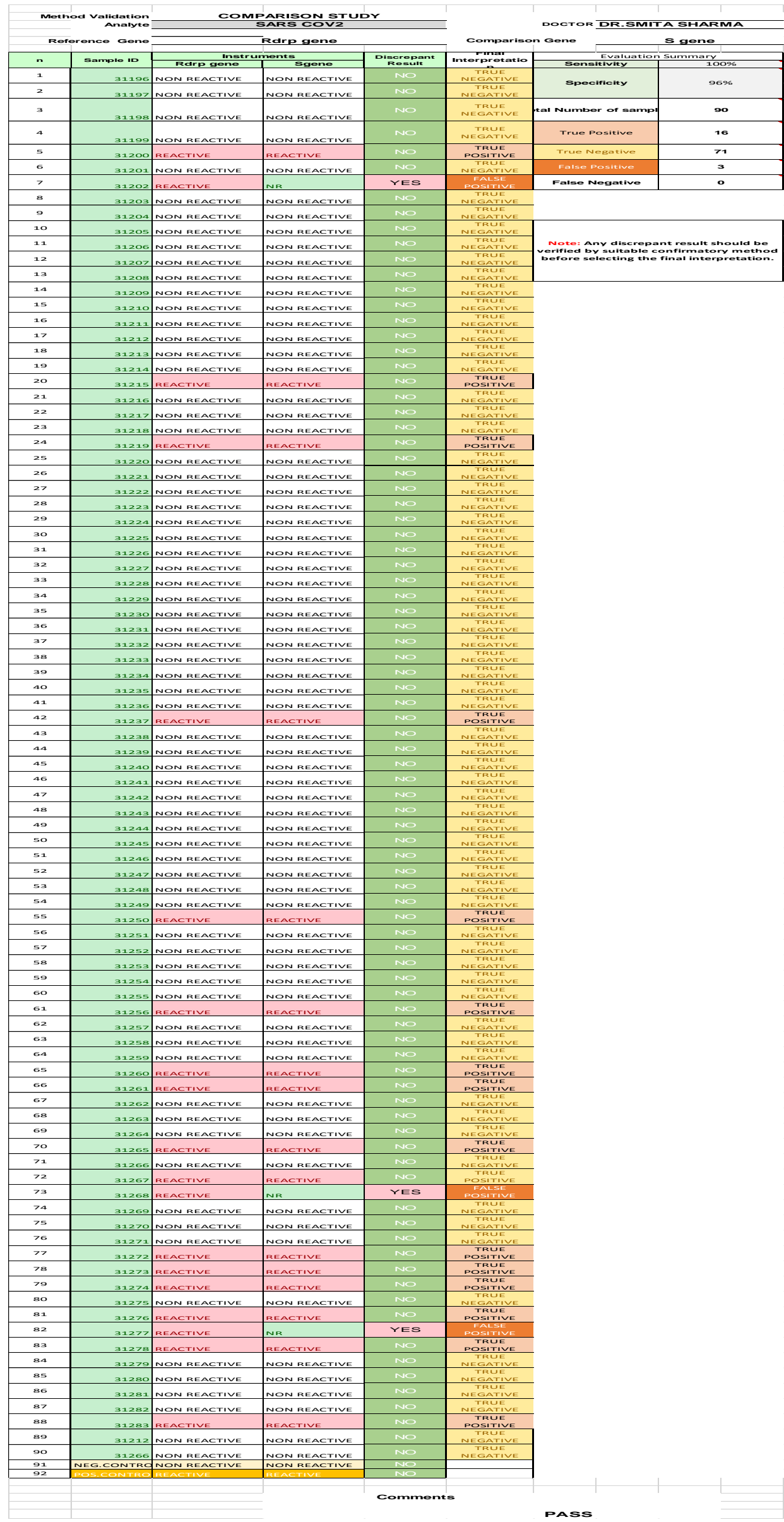


Smita Sharma et al.; Saudi J Med, Dec, 2020; 5(12): 367-374

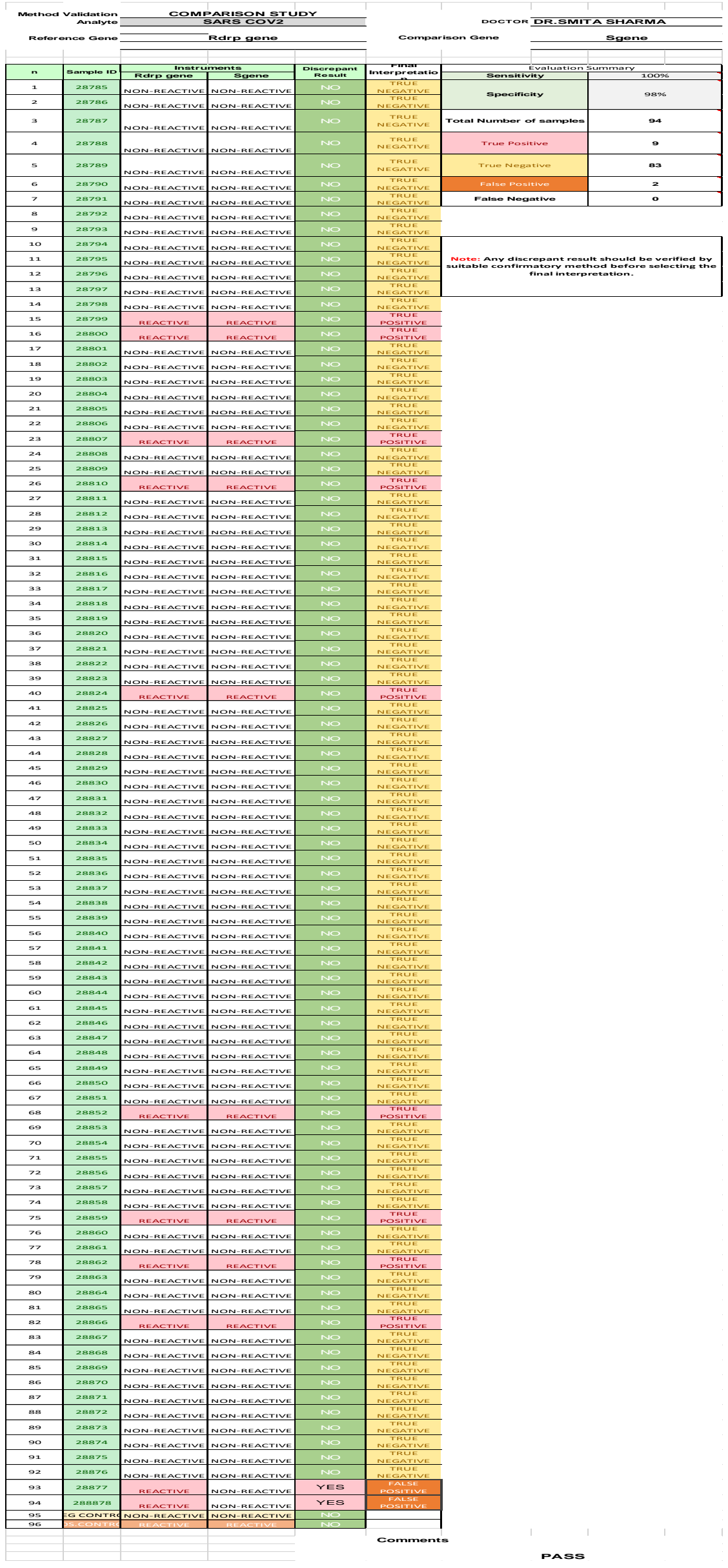


Smita Sharma et al.; Saudi J Med, Dec, 2020; 5(12): 367-374

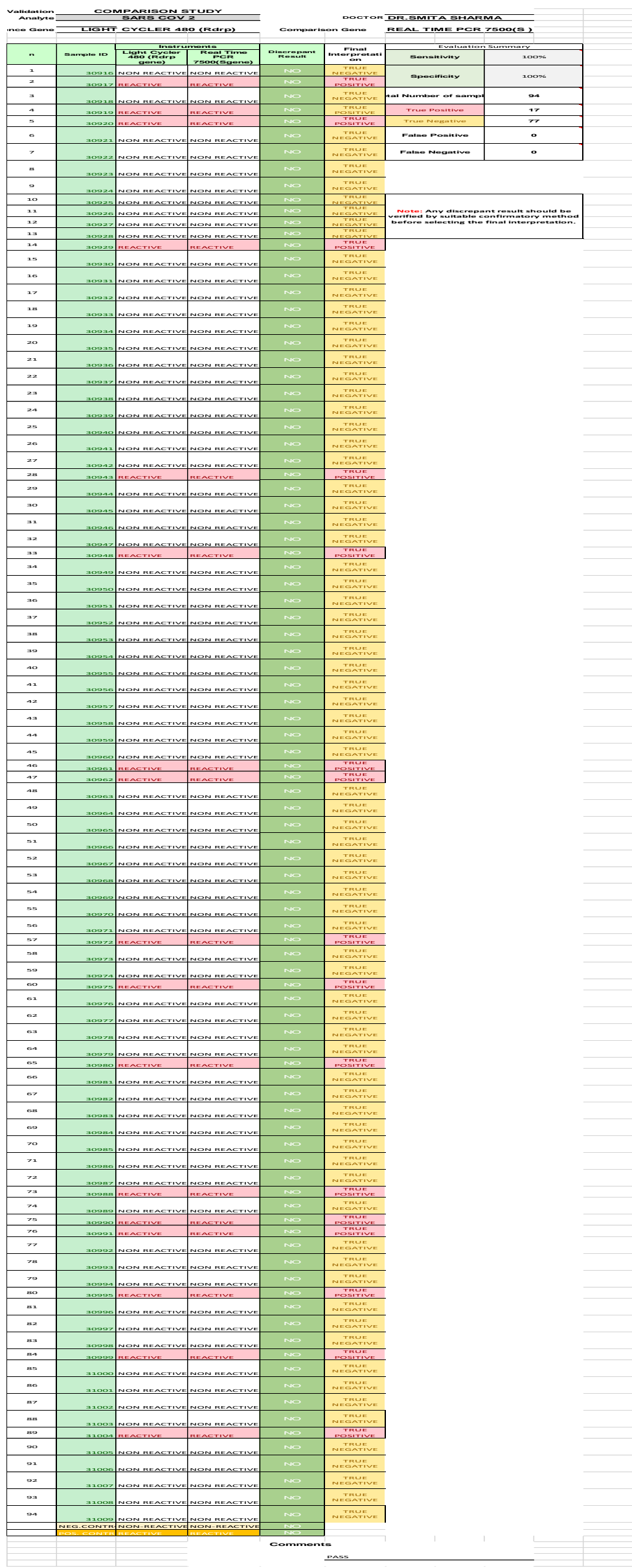




\section{DISCUSSION}

Regarding the different types of clinical specimens, the COVID-19-RdRp/Hel assay was significantly more sensitive than the RdRp-P2 assay for the detection of SARS-CoV-2 RNA in nasopharyngeal aspirates/swabs or throat swabs, saliva specimens, and plasma specimens. False-negative results might arise from testing nasopharyngeal aspirate/swabs or throat swabs with low viral loads in COVID-19, SARS, and MERS patients (9-13). RT-PCR assays with higher sensitivity, such as the COVID-19-RdRp/Hel assay, might help to reduce the false-negative rate among these specimens which are frequently the only specimens available for establishing the diagnosis of COVID-19.

The WHO recommended that the E gene assay followed by a confirmatory assay using the RdRp gene can be utilized for first line screening of COVID-19 cases; [14] and in the United States the CDC asked to use two nucleocapsid protein targets [N1 and N2] as a molecular assay [15]. It is advisable to use, at least two molecular targets to avoid the situation of a potential genetic drift of SARS-CoV-2 and the cross-reaction with other endemic coronaviruses as well, However, the ideal design would include at least one conserved region and one specific region to mitigate against the effects of genetic

Wong et al., used RdRp/Helicase gene combination in their study on 64 (51 known positives) patients and found sensitivity at 91\% [16]. Yip et al., on the other hand used Non-Structural Protein 2 (nsp2) with as target $100 \%$ analytical sensitivity [17]. In both sensitivity could not be measured. He et al. did with ORF 1ab (Open Reading Frame 1ab) 79\% sensitivity only 34 patients. The specificity was $100 \%$ [18]. Fang et al., studied it in 2 phases. First up they tested with ORF $1 \mathrm{ab}$, envelope gene (e-gene), and Nucleocapsid gene $(\mathrm{N})$ and had a sensitivity of $71 \%$. A study with a solo target (ORF1ab) in a large study had no significant analytical sensitivity/ specificity data [19]. A study by Liu et al., with Nucleocapsid Protein (NP) as a target has a similar sample size and outcome [20]. Ishige et $a l$., in their study developed a multiplex PCR targeting 3 genes Sarbeco-e gene, N-gene, and human abl1 as an internal control. This kit results perfectly matched with simplex PCR results with different targets [21]. Muenchoff et al., in a multicenter comparative study (seven laboratories) found RdRp to be lower sensitivity with the need to improve its sensitivity. However, the same study found CDC N1 primer/probe-based kits highly useful and sensitive [22].

\section{CONCLUSION}

Detection of Rdrp gene of SARS CoV 2 is more sensitive and specific than $\mathrm{S}$ gene.

Conflicts of Interests: There is no conflicts of interests.

\section{REFERENCES}

1. Fehr, A. R., \& Perlman, S. (2015). Coronaviruses: an overview of their replication and pathogenesis. In Coronaviruses (pp. 1-23). Humana Press, New York, NY.

2. Cui, J., Li, F., \& Shi, Z. L. (2019). Origin and evolution of pathogenic coronaviruses. Nature Reviews Microbiology, 17(3), 181-192.

3. Ruan, Y., Wei, C. L., Ling, A. E., Vega, V. B., Thoreau, H., Thoe, S. Y. S., ... \& Zhang, T. (2003). Comparative full-length genome sequence analysis of 14 SARS coronavirus isolates and common mutations associated with putative origins of infection. The Lancet, 361(9371), 17791785.

4. Masters, P. S. (2006). The molecular biology of coronaviruses. Advances in virus research, 66, 193-292.

5. Woo, P. C., Huang, Y., Lau, S. K., \& Yuen, K. Y. (2010). Coronavirus genomics and bioinformatics analysis. Viruses 2: 1804-1820.

6. Chan, J. F. W., Kok, K. H., Zhu, Z., Chu, H., To, K. K. W., Yuan, S., \& Yuen, K. Y. (2020). Genomic characterization of the 2019 novel human-pathogenic coronavirus isolated from a patient with atypical pneumonia after visiting Wuhan. Emerging microbes \& infections, 9(1), 221-236.

7. Wu, A., Peng, Y., Huang, B., Ding, X., Wang, X., Niu, P., ... \& Sheng, J. (2020). Genome composition and divergence of the novel coronavirus (2019-nCoV) originating in China. Cell host \& microbe. 27; 325-328.

8. Yang, D., \& Leibowitz, J. L. (2015). The structure and functions of coronavirus genomic $3^{\prime}$ and $5^{\prime}$ ends. Virus research, 206, 120-133.

9. Chan, J. F. W., Yuan, S., Kok, K. H., To, K. K. W., Chu, H., Yang, J., ... \& Tsoi, H. W. (2020). A familial cluster of pneumonia associated with the 2019 novel coronavirus indicating person-toperson transmission: a study of a family cluster. The Lancet, 395(10223), 514-523.

10. Peiris, J. S. M., Chu, C. M., Cheng, V. C. C., Chan, K. S., Hung, I. F. N., Poon, L. L., ... \& Chan, K. H. (2003). Clinical progression and viral load in a community outbreak of coronavirusassociated SARS pneumonia: a prospective study. The Lancet, 361(9371), 1767-1772.

11. Tsang, O. T. Y., Chau, T. N., Choi, K. W., Tso, E. Y. K., Lim, W., Chiu, M. C., ... \& Lai, J. Y. (2003). Coronavirus-positive nasopharyngeal aspirate as predictor for severe acute respiratory syndrome mortality. Emerging infectious diseases, 9(11), 1381-1387.

12. Corman, V. M., Albarrak, A. M., Omrani, A. S., Albarrak, M. M., Farah, M. E., Almasri, M., ... \& Binger, T. (2016). Viral shedding and antibody response in 37 patients with Middle East respiratory syndrome coronavirus 
infection. Clinical Infectious Diseases, 62(4), 477483.

13. Memish, Z. A., Al-Tawfiq, J. A., Makhdoom, H. Q., Assiri, A., Alhakeem, R. F., Albarrak, A., ... \& Kheyami, A. M. (2014). Respiratory tract samples, viral load, and genome fraction yield in patients with Middle East respiratory syndrome. The Journal of infectious diseases, 210(10), 15901594.

14. Corman, V. M., Landt, O., Kaiser, M., Molenkamp, R., Meijer, A., Chu, D. K., ... \& Mulders, D. G. (2020). Detection of 2019 novel coronavirus (2019-nCoV) by real-time RTPCR. Eurosurveillance, 25(3), 2000045.

15. Holshue, M. L., DeBolt, C., Lindquist, S., Lofy, K. H., Wiesman, J., Bruce, H., ... \& Diaz, G. (2020). First case of 2019 novel coronavirus in the United States. New England Journal of Medicine. 382:929-936.

16. Wong, H. Y. F., Lam, H. Y. S., Fong, A. H. T., Leung, S. T., Chin, T. W. Y., Lo, C. S. Y., ... \& Lee, E. Y. P. (2020). Frequency and distribution of chest radiographic findings in COVID-19 positive patients. Radiology, 201160.

17. Yip, C. C. Y., Ho, C. C., Chan, J. F. W., To, K. K. W., Chan, H. S. Y., Wong, S. C. Y., ... \& Tam, A. R. (2020). Development of a novel, genome subtraction-derived, SARS-CoV-2-specific COVID-19-nsp2 real-time RT-PCR assay and its evaluation using clinical specimens. International journal of molecular sciences, 21(7), 2574.

18. He, J. L., Luo, L., Luo, Z. D., Lyu, J. X., Ng, M. Y., Shen, X. P., \& Wen, Z. (2020). Diagnostic performance between CT and initial real-time RTPCR for clinically suspected 2019 coronavirus disease (COVID-19) patients outside Wuhan, China. Respiratory Medicine, 105980.

19. Fang, Y., Zhang, H., Xie, J., Lin, M., Ying, L., Pang, P., \& Ji, W. (2020). Sensitivity of chest CT for COVID-19: comparison to RTPCR. Radiology, 200432.

20. Liu, R., Han, H., Liu, F., Lv, Z., Wu, K., Liu, Y., ... \& Zhu, C. (2020). Positive rate of RT-PCR detection of SARS-CoV-2 infection in 4880 cases from one hospital in Wuhan, China, from Jan to Feb 2020. Clinica Chimica Acta. 505:172-175.

21. Ishige, T., Murata, S., Taniguchi, T., Miyabe, A., Kitamura, K., Kawasaki, K., ... \& Matsushita, K. (2020). Highly sensitive detection of SARS-CoV2 RNA by multiplex rRT-PCR for molecular diagnosis of COVID-19 by clinical laboratories. Clinica Chimica Acta. 507:139-142.

22. Muenchhoff, M., Mairhofer, H., Nitschko, H., Grzimek-Koschewa, N., Hoffmann, D., Berger, A., ... \& Zange, S. (2020). Multicentre comparison of quantitative PCR-based assays to detect SARSCoV-2, Germany, March 2020. Eurosurveillance, 25(24), 2001057. 